\title{
Efeito de Reticulante na Morfologia e Propriedades Físico-Mecânicas de Espumas Poliméricas Obtidas com EVA e EPDM
}

\author{
Joyce B. Azevedo, Manuel Alpire Chávez \\ Núcleo de Polímeros, SENAI CIMATEC
}

\author{
Marcelo S. Rabello \\ Unidade Acadêmica de Engenharia de Materiais, UFCG
}

\begin{abstract}
Resumo: Espumas poliméricas são materiais bifásicos constituídos por uma matriz polimérica sólida e por uma fase gasosa proveniente de um agente de expansão. Produtos obtidos com estes materiais vêm ganhando bastante espaço no mercado por apresentar boas propriedades mecânicas aliadas à baixa densidade e baixo custo. O uso de EVA com elastômeros tem sido uma alternativa para proporcionar propriedades mais nobres a esses compostos expansíveis. Dentre os elastômeros utilizados, o EPDM apresenta um potencial de aplicação elevado por apresentar boa compatibilidade com as poliolefinas. Como na fabricação da espuma tem-se simultaneamente reações de reticulação e de formação gases de expansão, o balanço desses efeitos tem forte influência sobre as características físicas do produto. Neste estudo, avaliou-se o efeito de um agente reticulante nas formulações de espumas de EVA/EPDM. As propriedades físico-mecânicas, reométricas e morfológicas de misturas EVA/EPDM com diversas proporções de peróxido de dicumila, utilizado como agente de reticulação, foram avaliadas. Os resultados mostraram que o teor de reticulante apresenta forte influência nas características técnicas das espumas obtidas.
\end{abstract}

Palavras-chave: Espumas poliméricas, EVA, EPDM, agente de reticulação, propriedades físico-mecânicas.

\section{The Effect of a Crosslinking Agent on the Morphology and Physical and Mechanical Properties of Polymer Foams Based on EVA and EPDM}

\begin{abstract}
Polymer foams are biphasic materials prepared with a polymer matrix and a gaseous phase from a foaming agent. Products based on this type of material are currently in a good market position due to the good mechanical properties, low density and competitive cost. Blending EVA with elastomers is a feasible alternative to enhance the properties of the expandable compounds. Among the elastomers used as a blend component with EVA, EPDM has a high potential since it has a good compatibility with polyolefins. Considering that during the foam processing there are simultaneous crosslinking reactions and the formation of gases, the balance between these two effects has a strong influence over the physical characteristics of the final product. In this study the effect of a crosslinking agent on EVA/ EPDM foams was investigated. The physical, mechanical and rheometric properties, as well as the foam morphology, were analyzed as a function of dicumil peroxide, used as a crosslinking agent. The results showed that this additive has a strong influence in the crooking and expansion of the compounds, affecting their properties.
\end{abstract}

Keywords: Polymer foam, EVA, EPDM, crosslinking agent, physical and mechanical properties.

\section{Introdução}

Espumas poliméricas, plásticos celulares ou plásticos expandidos podem ser definidos como materiais constituídos por uma fase sólida de uma matriz polimérica e por uma fase gasosa derivada de um agente expansor ${ }^{[1,2]}$. Embora existam também espumas rígidas, a maioria dos produtos comerciais são flexíveis e bastante utilizados em aplicações onde se requerem propriedades de absorção de impacto e de ruídos, leveza e maciez. Como resultado das características apresentadas, as espumas estão sendo amplamente utilizadas pelas indústrias aeronáutica e automobilística, em equipamentos para prática de esportes, calçados, brinquedos, embalagens e vários outros campos de aplicação, com uma significativa importância para o mercado por estar aliada a grandes vantagens técnicas e comerciais.

O uso do copolímero de etileno-acetato de vinila (EVA) como matriz polimérica em espumas, alia boas propriedades mecânicas, baixa densidade e reduzido custo. Este tipo de material celular tem apresentado crescente participação mercadológica nas últimas duas décadas e é conhecido usualmente como "placa expandida" por ser a forma como mais frequentemente se apresenta.
As espumas comerciais de EVA geralmente têm uma estrutura de célula fechada que consiste em inclusões de ar separadas por uma membrana de fase contínua e sólida, que pode ser rígida ou flexível. Pode ser obtida em uma ampla faixa de densidades, variando de 90 a $350 \mathrm{~kg} / \mathrm{m}^{3}$; dependendo do processo de expansão durante a fabricação ${ }^{[3]}$. Os constituintes típicos de uma espuma de EVA são essencialmente a matriz polimérica, agente de expansão, ativador, agente de reticulação, lubrificante, cargas e pigmentos. Dentre estes aditivos, o agente de reticulação é um dos componentes mais importantes uma vez que é responsável pela formação de reticulações químicas entre as cadeias da matriz. A ocorrência de reticulações, concomitantemente com a expansão do material, ambos ocorrendo durante o processamento, é primordial para obtenção de espumas com células menores e uniformes com melhores propriedades químicas, térmicas e mecânicas. De fato, a obtenção de espumas com células abertas ou fechadas está intimamente associada com a viscosidade da massa polimérica durante a evolução dos gases do agente de expansão. Como a viscosidade depende fortemente da ocorrência das reações de reticulação, esses fatores são interrelacionados e definirão o tipo 
de estrutura obtida. A Figura 1 mostra esquematicamente esses efeitos. Se a viscosidade da massa polimérica durante a reticulação, que depende da temperatura, massa molar e grau de reticulação, for mais baixa a matriz não consegue conter a pressão do gás, havendo ruptura e, assim, a obtenção de células abertas. Se a viscosidade for demasiadamente elevada a pressão do gás não expande suficientemente a espuma, obtendo-se um produto com baixo grau de expansão. A influência conjunta de agentes de expansão e de reticulação é portanto, um critério importante para a obtenção de espumas com propriedades planejadas. Esse tema já foi investigado anteriormente, por exemplo, em espumas de EVA/PE ${ }^{[4,5]}, \mathrm{PEBD}^{[6,7]}$ e $\operatorname{EPDM}^{[8]}$.

Em baixas concentrações (até 20 pcr) alguns elastômeros insaturados, como o EPDM, são miscíveis com o $\mathrm{EVA}^{[9]}$. A presença das duplas ligações desses elastômeros, entretanto, altera significativamente a cinética de cura do sistema, modificando o perfil da curva reométrica com redução no tempo de $\operatorname{scorch}{ }^{[10]}$.

Nos polímeros termoplásticos saturados, incluindo poliolefinas como o EVA, a reticulação ocorre pela abstração do hidrogênio ligado ao carbono terciário ${ }^{[11]}$. Essa reação é favorecida pelos radicais livres formados na decomposição dos peróxidos orgânicos. Nos casos em que existam grupos vinílicos na cadeia principal, como, por exemplo, resultado de desvios nos processos de polimerização, a reação de reticulação torna-se favorecida ${ }^{[12]}$. No caso do copolímero EVA a eficiência da reação de reticulação depende da concentração de acetato de vinila, que define o número de carbonos terciários ao longo da cadeia. A presença do copolímero etileno-propilenodieno (EPDM), que possui grupos insaturados originários do monômero dieno, proporciona uma reticulação mais rápida dos compostos com EPDM quando comparado com os compostos só com $\mathrm{EVA}^{[13,14]}$ pois as insaturações são sítios preferenciais para reação a partir dos radicais livres gerados pelos peróxidos ${ }^{[10]}$. Isso provoca, simultaneamente, efeitos relevantes na expansão da borracha que, como mencionado anteriormente, é fortemente dependente da viscosidade e reticulação da matriz (Figura 1). Além disso, as propriedades elásticas podem ser melhoradas com a adição do EPDM, o que só seria conseguido, sem a presença desse componente, com o uso de um tipo de EVA contendo maior teor de acetato de vinila e, portanto, menos cristalino. Vale salientar que a presença de radicais livres, como os originados dos peróxidos, podem provocar tanto reações de reticulação quanto de degradação, dependendo da natureza química da estrutura macromolecular, da presença de oxigênio, dentre outros fatores ${ }^{[11,15,16]}$.

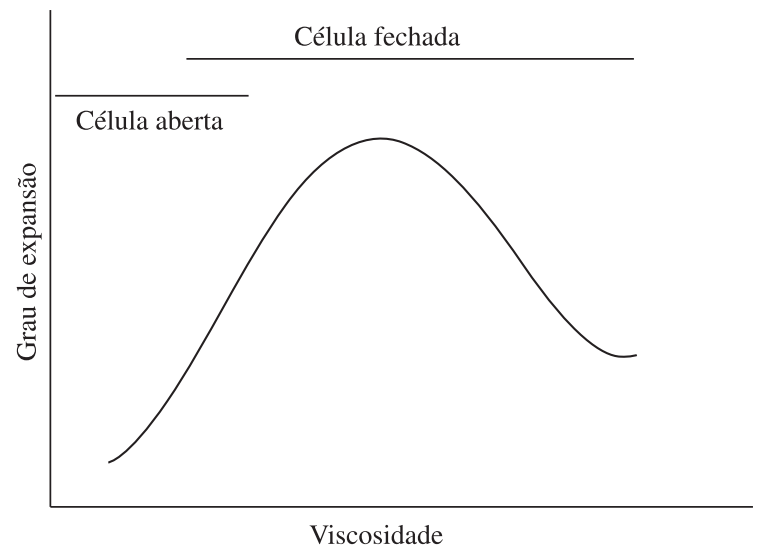

Figura 1. Representação esquemática do efeito da viscosidade no grau de expansão de borrachas ${ }^{[2]}$.
Características da mistura de EVA/EPDM já foram enfatizadas anteriormente quanto à suas propriedades térmicas e mecânicas ${ }^{[17]}$, cinética de reticulação ${ }^{[18]}$ e propriedades elétricas ${ }^{[19]}$. Entretanto, porém poucos trabalhos na literatura técnica foram identificados tratando da combinação destes dois copolímeros na forma expandida, mesmo estando estes materiais com boas perspectivas de utilização industrial. Liu \& Lin $^{[19]}$, mostraram que blendas ternárias de EVA com EPDM e poli(cloropreno) poderiam ser produzidas por injeção na presença de agentes químicos de expansão e de agentes de cura.

A etapa de reticulação é considerada crítica durante o processamento de espumas, pois os peróxidos podem gerar reações químicas indesejáveis ocasionando degradações, ciclizações, recombinações, etc. A quantidade de peróxido utilizada em formulações para obtenção de espumas tem influência nas propriedades finais do produto, tanto devido à definição de suas estruturas reticuladas quanto à formação da estrutura celular. Com base nas informações acima, o presente trabalho avaliou o efeito do peróxido de dicumila como agente de reticulação nas propriedades de espumas poliméricas obtidas a partir da mistura de EVA com EPDM. Misturas foram preparadas com várias concentrações do reticulante e as espumas moldadas foram caracterizadas quanto às propriedades físicas e mecânicas.

\section{Experimental}

\section{Materiais}

No presente trabalho utilizou-se ingredientes e formulações típicas para obtenção de espumas de EVA com média densidade, aplicadas industrialmente para componentes de calçados.

Como matriz polimérica utilizou-se o EVA de grade comercial Evateno 3019 PE, fornecido pela Braskem. Segundo ficha técnica do material, trata-se de uma resina semi-cristalina com médio teor de acetato de vinila e facilmente reticulável. Utilizou-se a borracha de EPDM de grade comercial NORDEL IP 4570, produzida pela Dow Química, com relação 50/45/5 de etileno, propileno e norborneno respectivamente. $\mathrm{O}$ agente de expansão foi o azodicarbonamida, ativado com óxido de zinco, de grade comercial T-88 fornecido pela Inbra. Como agente de reticulação, utilizou-se o peróxido de dicumila de nome comercial Perkador BCff fornecido pela Akzo. O lubrificante utilizado foi a esteriana, com faixa de fusão entre 55 e $65{ }^{\circ} \mathrm{C}$, adequado para as condições de processamento dos demais componentes. Como carga utilizou-se um carbonato de cálcio precipitado de nome comercial Extra Leve AA fornecido pela Quimvale, com granulometria na faixa de 1,4-2,2 $\mu \mathrm{m}$. Estudos anteriores realizados pelos autores mostraram que este tipo de carbonato de cálcio confere propriedades físicas a espumas de EVA sensivelmente superiores a outros carbonatos estudados ${ }^{[20]}$.

\section{Formulação das espumas}

Nas formulações estudadas as concentrações de EVA/EPDM foram mantidas constantes na proporção 70/30 e variou-se a concentração de agente de reticulação. A concentração de EVA/EPDM foi definida através da comparação dos resultados preliminares entre os valores de densidade, deformação permanente por compressão (DCP) e resiliência com os valores destas propriedades utilizadas para produção de entressolas fabricadas com EVA e outros materiais utilizados em tênis esportivos ${ }^{[21]}$. A Tabela 1 mostra as composições das espumas utilizadas.

\section{Preparação das espumas}

As espumas foram obtidas através de uma metodologia padrão utilizada em todas as formulações. A primeira etapa da preparação 
Tabela 1. Composição das espumas EVA/EPDM.

\begin{tabular}{cc}
\hline Componente & pcr $^{(\mathbf{1})}$ \\
\hline EVA (matriz) & 70 \\
EPDM (matriz) & 30 \\
Azodicarbonamida (agente expansor) & 7 \\
Peróxido de dicumila (agente de reticulação) & 0,2 a 1,2 \\
Estearina (lubrificante) & 1,5 \\
Carbonato de cálcio (carga) & 15 \\
\hline
\end{tabular}

${ }^{(1)}$ Partes do componente por 100 partes da matriz.

consistiu na mistura dos componentes em um misturador de rolos da marca Cope a uma temperatura de $90{ }^{\circ} \mathrm{C}$, suficiente para plastificar o EVA. Nesta técnica a adição dos ingredientes é sequencial, sendo iniciado com o EVA, seguido do EPDM, carga e lubrificante. Após completa homogeneização desses componentes foi adicionado o peróxido de dicumila e a azodicarbonamida ativada. Nesta etapa, a mistura não ultrapassou 5 minutos para que não ocorresse reticulação e expansão prematuras do composto. Passada a etapa de mistura em cilindro, as lâminas foram cortadas com gabarito circular de 150 mm de diâmetro, resfriadas e deixadas em repouso, na temperatura ambiente.

\section{Expansão e reticulação}

Os compostos foram reticulados e expandidos durante a moldagem por compressão a $170{ }^{\circ} \mathrm{C}$ e $60 \mathrm{kgf.cm}{ }^{-2}$ em prensa hidráulica da marca Advanced. A velocidade de abertura da prensa foi de $200 \mathrm{~mm} / \mathrm{seg}$, garantindo boa uniformidade da estrutura celular.

Nessa etapa utilizou-se um molde circular confeccionado com aço 1040, como mostrado na Figura 2. Todo o molde tem contato com os platôs da prensa para melhorar a transferência de calor, visando diminuir as variações nas propriedades das espumas. Estudos anteriores mostraram que as propriedades da espuma podem variar consideravelmente com a posição no molde, pela dificuldade da transferência de calor, a partir da parede até o interior do composto ${ }^{[22]}$.

\section{Análise reométrica}

Para determinação do tempo ideal de processamento por compressão das espumas foram realizados estudos sobre os parâmetros cinéticos de reticulação utilizando um reômetro de disco oscilatório, fabricado pela Alpha Technologies, modelo MDR 2000P, operando a $170{ }^{\circ} \mathrm{C}$ durante 10 minutos. Nessas análises utilizou-se compostos de EVA/EPDM em diferentes proporções sem adição de expansor, mas contendo os demais ingredientes. A partir das curvas reométricas obtidas determinou-se os valores de torque máximo, torque mínimo, tempo de pré-cura e tempo ótimo de cura.

\section{Caracterização físico-mecânica}

A densidade dos corpos de prova foram medidas segundo norma ASTM D-792 seguindo o princípio de Arquimedes. Os ensaios de resiliência foram realizados segundo norma DIN 53512, utilizando um resiliômetro da marca MAQTEST. A dureza foi medida segundo a ASTM 2240, em equipamento da marca Woltest. Realizou-se medidas na superfície da espuma (dureza externa) e no interior da espuma após corte de sua seção transversal (dureza interna).

A deformação permanente por compressão foi determinada pela norma ASTM D 3575, utilizando um dispositivo constituído por duas placas metálicas paralelas, cuja distância entre elas é regulada por parafusos.

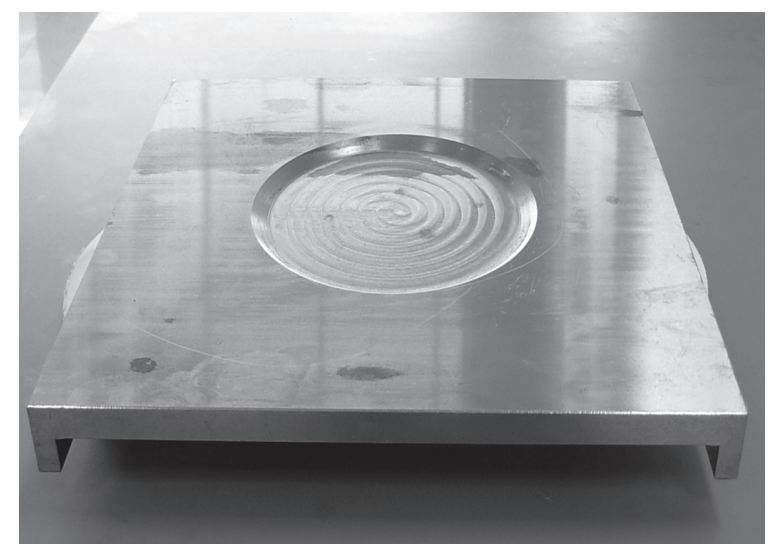

Figura 2. Molde utilizado para obtenção das espumas.

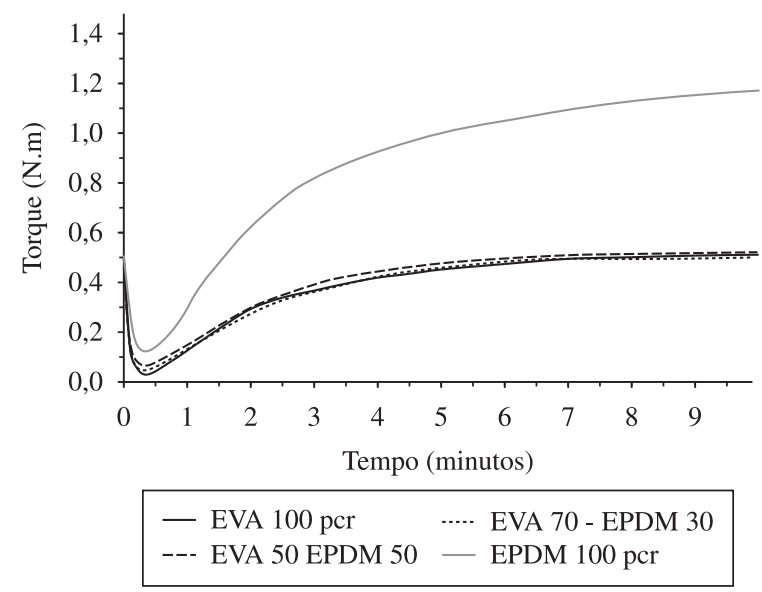

Figura 3. Torque em função do tempo de compostos com diferentes concentrações de EVA/EPDM.

As espumas também foram submetidas a ensaio mecânico de tração em uma máquina universal de ensaios da EMIC, modelo DL 2000, segundo norma ASTM D412-06, sendo os corpos de prova obtidos através do corte da espuma com auxílio de um cunho. Analisou-se o módulo elástico, a tensão e a deformação na ruptura. Os resultados reportados em todos esses testes representam médias de pelo menos 4 determinações.

\section{Caracterização morfológica}

A morfologia das amostras foi caracterizada através de microscopia eletrônica de varredura após recobrimento com ouro para evitar acúmulo de cargas estáticas. Utilizou-se microscópio da marca Shimadzu, modelo SSX-550, operando com voltagem de 5 a $15 \mathrm{KV}$. O ensaio foi realizado na superfície transversal das amostras, cortadas com auxílio de um bisturi.

\section{Resultados e Discussão}

\section{Análise reométrica}

Neste estudo foram realizadas análises reométricas para caracterização dos parâmetros cinéticos de reticulação nas espumas, já que as propriedades apresentadas por estes materiais possuem uma forte dependência com o nível de reticulação apresentado pela espuma $^{[10]}$.

A Figura 3 mostra as curvas de torque em função do tempo para compostos com diferentes proporções de EVA/EPDM. Os resultados obtidos com esta análise estão compilados na Tabela 2. Embora os testes tenham sido realizados apenas com uma amostra de cada tipo, 
Tabela 2. Formulações e parâmetros de reticulação dos compostos com EVA e EPDM.

\begin{tabular}{cccccc}
\hline \multicolumn{3}{c}{ Formulações } & \multicolumn{4}{c}{ Parâmetros de vulcanização } \\
\hline $\begin{array}{c}\text { EVA } \\
\text { (pcr) }\end{array}$ & $\begin{array}{c}\text { EPDM } \\
\text { (pcr) }\end{array}$ & $\begin{array}{c}\text { Torque } \\
\text { mínimo } \\
\text { (N.m) }\end{array}$ & $\begin{array}{c}\text { Torque } \\
\text { máximo } \\
\text { (N.m) }\end{array}$ & $\begin{array}{c}\text { Tempo de } \\
\text { pré cura T10 } \\
\text { (minutos) }\end{array}$ & $\begin{array}{c}\text { Tempo ótimo } \\
\text { de cura T90 } \\
\text { (minutos) }\end{array}$ \\
\hline 100 & 0 & 0,029 & 0,526 & 1,808 & 6,518 \\
70 & 30 & 0,047 & 0,518 & 1,935 & 6,264 \\
50 & 50 & 0,049 & 0,559 & 1,820 & 6,332 \\
0 & 100 & 0,141 & 1,176 & 0,955 & 6,074 \\
\hline
\end{tabular}

a precisão neste tipo de ensaio é bastante elevada, oferecendo uma boa indicação nas tendências observadas. Observa-se na Tabela 2 um acréscimo de $55 \%$ do valor de torque máximo obtido no composto com 100 pcr de EPDM quando comparado com o torque máximo obtido na formulação com 100 pcr de EVA. A variação de torque entre as amostras com 100, 70 e 50 pcr de EVA foram pequenas, com um discreto aumento deste parâmetro para a amostra com 50 pcr de EPDM. Comportamento semelhante foi reportado em outro estudo ${ }^{[14]}$, onde os valores de torque máximo aumentaram com o aumento da concentração de EPDM e agente de expansão em formulações utilizadas para espumas obtidas por injeção. Segundo Soares ${ }^{[23]}$, os valores de torque máximo, medidos a pequenas deformações, são normalmente proporcionais à densidade de reticulações.

O EVA é um polímero completamente saturado sendo necessário o uso de agentes de reticulação, geralmente peróxidos, que geram radicais livres pela sua decomposição os quais reagem quimicamente com as cadeias do polímero. Por outro lado, o EPDM possui um dieno não conjugado como terceiro monômero que possui insaturações, permitindo uma melhor reticulação em determinadas posições da estrutura polimérica sem afetar a cadeia molecular principal, que é totalmente saturada.

A equação cinética que descreve o processo de reticulação pode ser obtida através dos valores de torque e tempo dos reogramas gerados nos ensaios em reômetro de disco oscilatório ${ }^{[23]}$. Se o processo for considerado como uma reação de primeira ordem, este pode ser expresso pela Equação 1:

$$
\ln \left(T_{\max }-T_{\text {tempo }}\right)=K \bullet \ln \left(T_{\max }-T_{\min }\right)
$$

onde $\mathrm{T}_{\max }, \mathrm{T}_{\text {tempo }}, \mathrm{T}_{\min }$ e $\mathrm{K}$ são, respectivamente, torques máximos, torque no tempo de cura $\mathrm{t}$, torque mínimo e constante cinética de vulcanização.

A partir da Equação 1, construiu-se o gráfico do $\ln \left(\mathrm{T}_{\max }-\mathrm{T}_{\text {tempo }}\right)$ contra o tempo, mostrado na Figura 4. Observa-se que em todas as formulações tem-se uma relação aproximadamente linear, indicando que a reticulação nas formulações seguem uma cinética de primeira ordem. Através do coeficiente angular obtido nas curvas é possível determinar a constante cinética de reticulação $(\mathrm{K})^{[23]}$. Estes valores estão mostrados na Tabela 3.

Os maiores resultados obtidos, tanto para o torque máximo como para a constante cinética de reticulação, foi na formulação com 100 pcr de EPDM, ou seja, o uso do EPDM nas formulações de compostos expansíveis torna a formação de reticulações mais eficiente devido à presença, na sua estrutura química, de um dieno não conjugado. Essa influência deve afetar não apenas as propriedades mecânicas do composto mas também a expansão das espumas. De fato, isso foi observado em estudos anteriores dos mesmos autores ${ }^{[24]}$.

\section{Propriedades físico-mecânicas}

\section{Densidade}

A Figura 5 apresenta a variação da densidade para as espumas em função da concentração do agente de reticulação nos compostos
Tabela 3. Constante cinética de vulcanização dos compostos EVA/EPDM.

\begin{tabular}{ccc}
\hline \multicolumn{2}{c}{ Formulações } & $\begin{array}{c}\text { Constante cinética de vulcanização } \\
\text { K (min }\end{array}$ \\
\cline { 1 - 2 } EVA (pcr) & EPDM (pcr) & 0,3884 \\
700 & 0 & 0,4002 \\
50 & 30 & 0,3597 \\
0 & 50 & 0,4228 \\
\hline
\end{tabular}

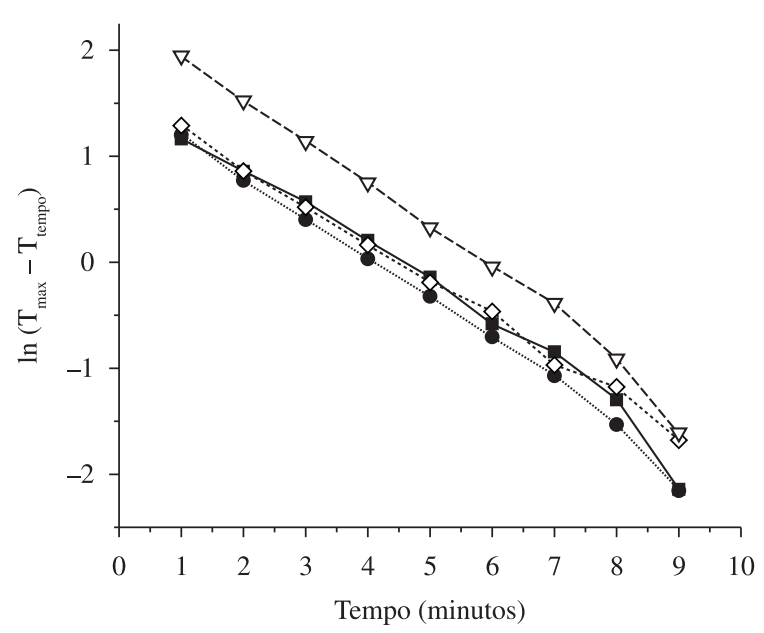

- 100 pcr EVA $\quad \cdots \cdots \cdots$ pcr EVA 30 pcr EPDM $\checkmark 50$ pcr EVA 50 pcr EPDM $\quad-\nabla-100$ pcr EPDM

Figura 4. Gráfico de $\ln \left(\mathrm{T}_{\max }-\mathrm{T}_{\text {tempo }}\right)$ em função do tempo de mistura das formulações EVA/EPDM obtido a partir de análise reométrica.



Figura 5. Densidade das espumas de EVA/EPDM em função da concentração do agente de reticulação.

expansíveis obtidos. Observa-se que à medida que se aumenta a concentração de agente de reticulação, obtém-se espumas mais densas, como consequência de uma maior viscosidade da massa borrachosa (conforme princípio mostrado na Figura 1) e verificado anteriormente $^{[5]}$. O gás gerado pelo agente de expansão não possui pressão suficiente, restringindo a expansão do material. Por outro lado, se o teor de peróxido for baixo, o grau de reticulação será baixo, resultando na formação de células maiores e sem uniformidade no seu tamanho, podendo, inclusive, gerar um produto de células abertas - indesejável na maioria das aplicações.

Durante a compressão da espuma, o expansor e o agente de reticulação reagem dentro do molde e a nucleação do gás é iniciada enquanto a matriz reticulada é formada. No fim do ciclo de 
compressão, quando o molde é aberto, as bolhas crescem quase que instantaneamente. Com a estrutura reticulada formada, o fundido possui resistência suficiente para conter o crescimento das bolhas. Com o aumento da quantidade de agente de reticulação e na presença de um componente polimérico com insaturações na formulação da espuma de EVA, o crescimento das bolhas é restringido resultando em uma espuma com células menores o que resultará em espumas com maiores valores de densidade.

\section{Dureza}

Na Figura 6 observam-se os valores de dureza interna e externa para os compostos expandidos em função da concentração do agente de reticulação. A dureza apresentou valores crescentes com o aumento da concentração de peróxido orgânico, seguindo a mesma tendência da densidade (Figura 5). Observa-se que as medidas de dureza externa, quando comparadas às de dureza interna, são maiores para todas as formulações. Este comportamento é explicado pela formação de uma pele mais densa e dura do que o resto da espuma durante o processo de expansão por compressão. A pele fica junto ao molde a uma temperatura mais elevada e durante mais tempo que o resto da espuma, o que aumenta o grau de reticulação, inibindo a expansão e, consequentemente, aumentando a dureza ${ }^{[20]}$. A Figura 7 mostra uma imagem microscópia da seção transversal de espuma de EVA similar e produzida no mesmo laboratório ${ }^{[2]}$. Notase claramente a pele mais densa e com menor número de células em comparação com a parte interna. Na região mais externa da pele, as células praticamente não existem ou são muito pequenas, aumentando progressivamente na direção do interior da espuma.

\section{Resiliência}

A resiliência é uma medida da quantidade de energia devolvida após a aplicação de uma esforço de impacto na placa expandida. A determinação desta propriedade é importante principalmente para solados destinados a calçados esportivos que visam um maior conforto e desempenho.

Na Figura 8 tem-se os resultados da resiliência para as formulações estudadas. Observa-se uma tendência de aumento nos valores desta propriedade com o aumento da concentração de agente de reticulação até 0,8 pcr, quando se tem uma aparente estabilização nessa propriedade. A propriedade de resiliência esta associada à diminuição de caráter elastomérico da espuma, já que este fator é responsável pela resposta à deformação sofrida na espuma pelo golpe do pêndulo do resiliômetro.

A resiliência é determinada pela relação entre a energia mecânica necessária para ocorrer a deformação do material e a energia mecânica liberada pela espuma ao tentar impedir esta deformação, procurando novamente adquirir a sua forma original. Com base nestas informações pode-se relacionar a densidade da espuma com a resiliência, ou seja, quanto maior a densidade maior a energia necessária para que a espuma mantenha sua forma original quando submetida ao golpe do pêndulo e, conseqüentemente, maior a sua resiliência. É possível que o aumento da resilência com o teor de agente reticulante esteja relacionado com as características viscoelásticas do material. Segundo esse princípio, os polímeros apresentam, simultaneamente, propriedades de um líquido viscoso e de um sólido elástico, sendo responsável por propriedades como relaxação de tensão, fluência e amortecimento ${ }^{[25]}$. Com o aumento no percentual de reticulação de uma borracha, espera-se que sua natureza viscosa seja reduzida e que o caráter elástico seja aumentado. O aumento na resiliência pode ser atribuído a maior natureza elástica do material com um maior percentual de reticulação.

\section{Deformação Permanente por Compressão (DPC)}

Por meio do teste de DPC, pode-se verificar a capacidade dos compostos reticulados em reter propriedades elásticas depois



Figura 6. Dureza (interna e externa) das espumas de EVA/EPDM em função da concentração do agente de reticulação.

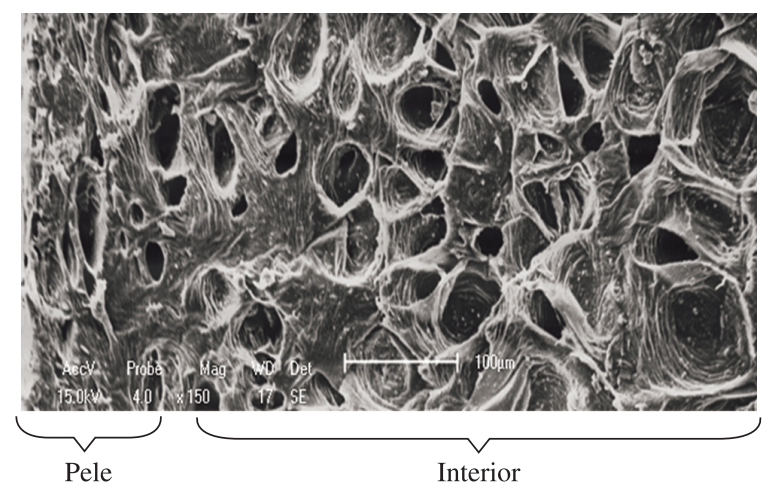

Figura 7. Microscopia de espuma EVA. Diferença de tamanho celular entre a pele e interior da espuma ${ }^{[22]}$.

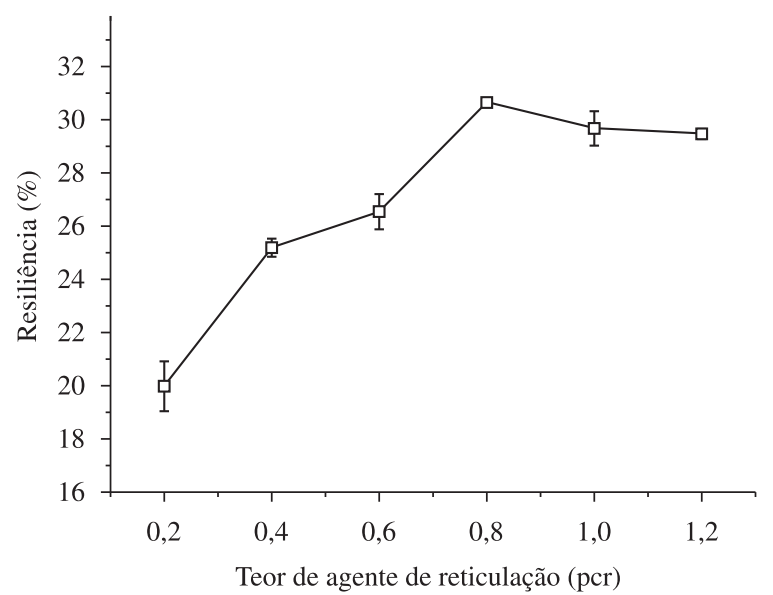

Figura 8. Resiliência das espumas de EVA/EPDM em função da concentração do agente de reticulação.

de ações prolongadas de esforços de compressão. Para materiais microcelulares de alta performance é desejável baixa densidade, baixa DPC e alta resiliência. Estas características garantem um material mais confortável, durável e leve quando da sua utilização na fabricação de calçados. Entretanto, para se obter baixa DPC normalmente o artefato deve possuir alta densidade, o que compromete a leveza e o conforto. 
A Figura 9 mostra os resultados obtidos de DPC a $23{ }^{\circ} \mathrm{C}$ para as espumas obtidas com variação de agente de reticulação, indicando uma tendência de diminuição de DPC com o aumento da concentração de agente de reticulação. A diferença de propriedade entre as espumas contendo 0,2 e 1,2 pcr de agente de reticulação foi de aproximadamente $70 \%$. O maior teor de peróxido utilizado aumenta o grau de reticulação, o que pode provocar melhoria na DPC, mas com maiores valores de densidade e dureza.

Em estudos realizados por Almeida ${ }^{[1]}$, foram avaliadas a DPC de espumas de PEBD com incorporação de polietileno pós consumo, observando-se que os valores obtidos para esta propriedade aumentaram com o aumento da concentração do resíduo do PE. O autor atribuiu este comportamento à diminuição da flexibilidade da espuma com a presença de resíduo. De forma semelhante, pode-se associar a diminuição da DPC para as formulações com maiores concentrações de agentes de reticulação com a ocorrência de um maior grau de reticulação o que inibe a expansão do material, tornando-o menos flexível.

\section{Propriedades mecânicas}

O módulo elástico é uma medida indireta da rigidez do material Quanto maior o módulo elástico menos deformação sofre o material quando submetido a uma tensão mecânica. Em espumas poliméricas, espera-se que quanto menor a sua densidade, maior a deformação e, consequentemente, menor o módulo elástico. Observa-se na Figura 10 que os valores dos módulos elásticos foram crescentes a medida que aumentou-se a concentração de agentes de reticulação.



Figura 9. DPC das espumas de EVA/EPDM em função da concentração do agente de reticulação.

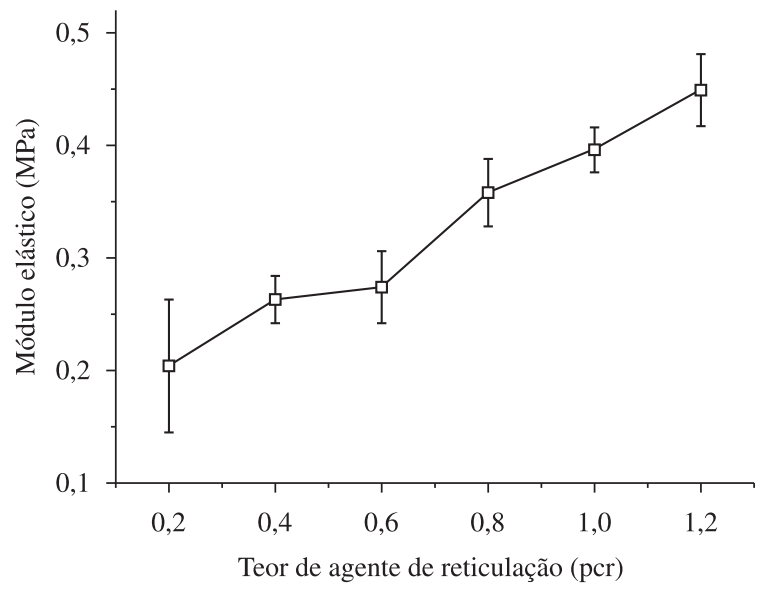

Figura 10. Módulo Elástico das espumas de EVA/EPDM em função da concentração do agente de reticulação.
A comparação entre as propriedades de densidade e módulo elástico para as formulações com diferentes concentrações de EPDM está ilustrada na Figura 11. Nota-se uma grande similaridade de comportamento entre as duas propriedades mensuradas.

A variação da resistência à tração com o teor de agente reticulante seguiu a mesma tendência do módulo elástico, mostrando um aumento progressivo com o percentual de reticulante presente (Figura 12). Devido às condições utilizadas no processamento dessas espumas, pode-se associar o aumento do grau de reticulação com o aumento da densidade da espuma e a sua dureza, pela restrição da expansão e, consequentemente, com o aumento da tensão necessária para que a ruptura do material.

Os resultados de deformação na ruptura estão mostrados na Figura 13. Observa-se que, ao contrário das demais propriedades mecânicas, a variação não é sistemática com a concentração do agente de reticulação. É possível que duas influências opostas estejam interferindo nesta propriedade: (i) a maior concentração do agente de reticulação aumenta a rigidez da espuma (Figura 10), o que restringe a capacidade de deformação e (ii) as propriedades elásticas de um material elastomérico, até determinado grau de reticulação, são melhoradas com a presença de ligações cruzadas que atuam como um ancoramento entre as cadeias. Resultados semelhantes aos mostrados aqui foram observados por Liu \& $\operatorname{Lin}^{[14]} \mathrm{em}$ espumas de EVA/EPDM e um elastômero poliolefínico clorado (CPE) como agente de compatibilização entre os dois polímeros.

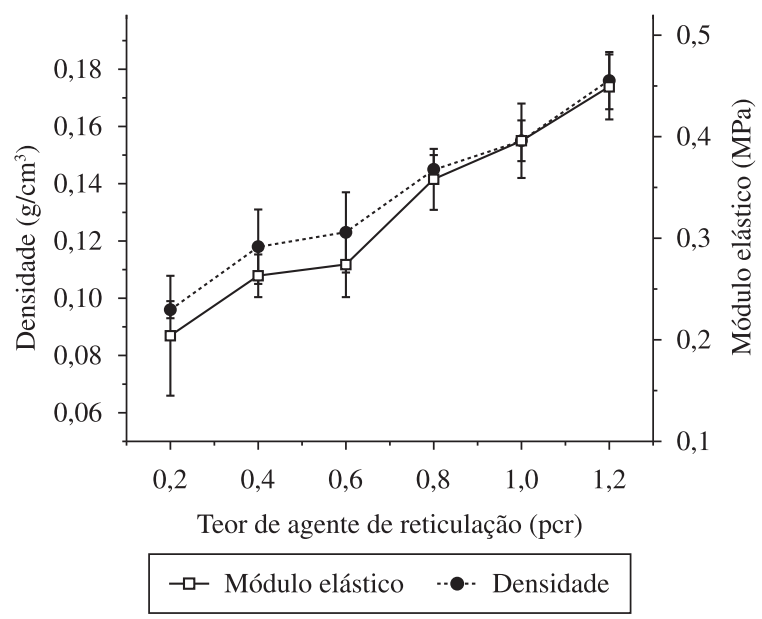

Figura 11. Comparação entre as propriedades de densidade e módulo elástico de espumas EVA/EPDM em função da concentração de agente de reticulação.

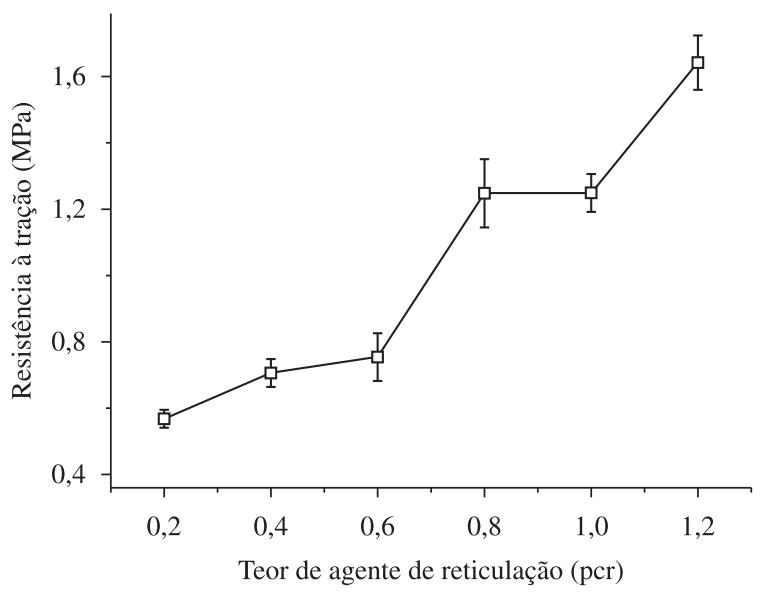

Figura 12. Resistência a tração das espumas de EVA/EPDM em função da concentração do agente de reticulação. 


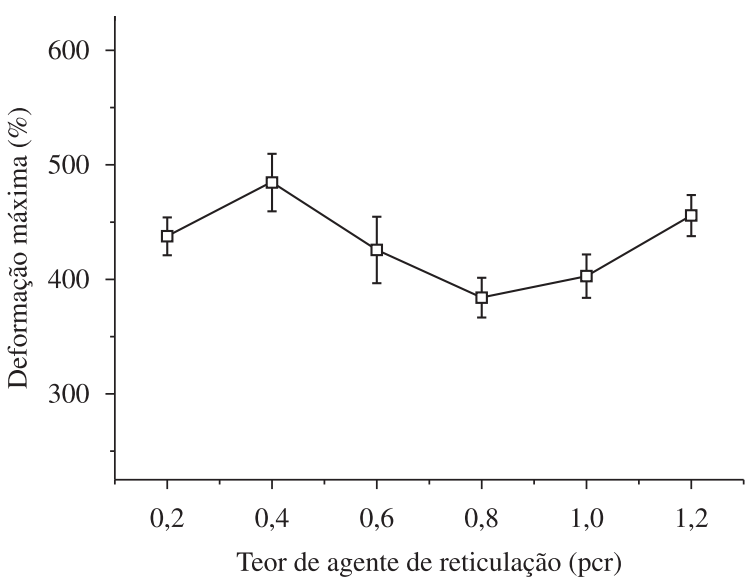

Figura 13. Deformação máxima das espumas de EVA/EPDM em função da concentração de agente de reticulação.

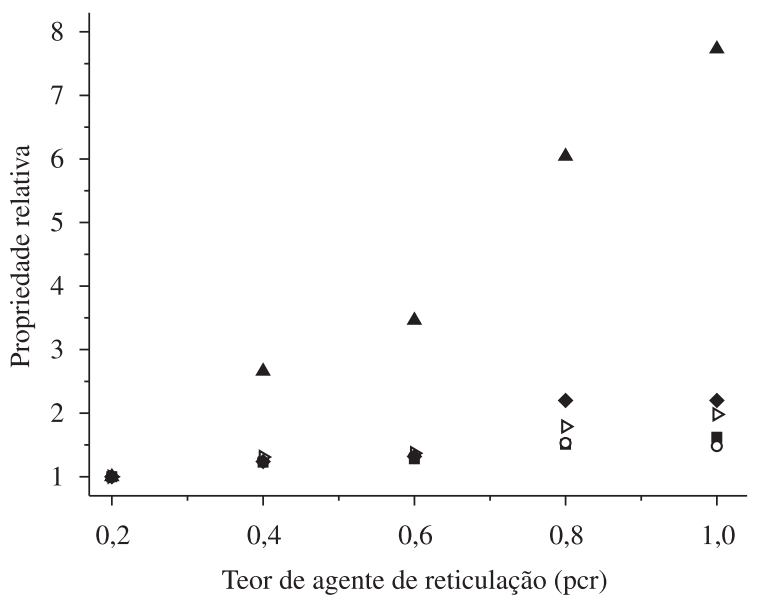

- Densidade $\circ$ Resiliência $\triangleright$ Módulo elástico $\Delta$ Dureza (externa) • Resistência tênsil

Figura 14. Variação relativa das propriedades das espumas de EVA/EPDM em função da concentração de agente de reticulação. A propriedade relativa foi determinada em relação à composição com 0,2 pcr de peróxido de dicumila.

A Figura 14 mostra um comparativo de várias propriedades analisadas nesse estudo. Os dados foram plotados como variação relativa da propriedade, ou seja, valor da propriedades em certa concentração de peróxido em relação à mesma propriedade com a composição-base de 0,2 pcr de peróxido de dicumila. Observa-se com esses dados que as propriedades de módulo elástico, resiliência, densidade e resistência mecânica apresentaram uma variação similar com o aumento da concentração de reticulante. Por outro lado, a dureza externa mostrou-se muito mais sensível à reticulação da espuma, com um aumento proporcionalmente bem maior nessa propriedade. Do ponto de vista prático, trata-se de um resultado interessante para alguns setores industriais como o de calçados. Nesse campo de aplicação um balanço de propriedades como alta resiliência, dureza elevada e baixa deformação permanente por compressão (DPC) podem ser altamente desejáveis. Nos resultados apresentados neste estudo observou-se que, de fato, composições com EPDM e peróxido de dicumila apresentaram baixa DPC (Figura 9), elevada dureza e um aumento relativamente pequeno na densidade (Figura 14).

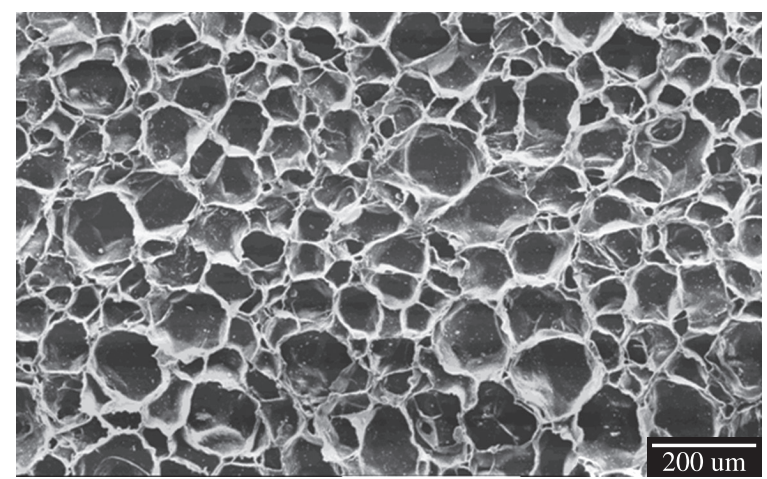

(a)

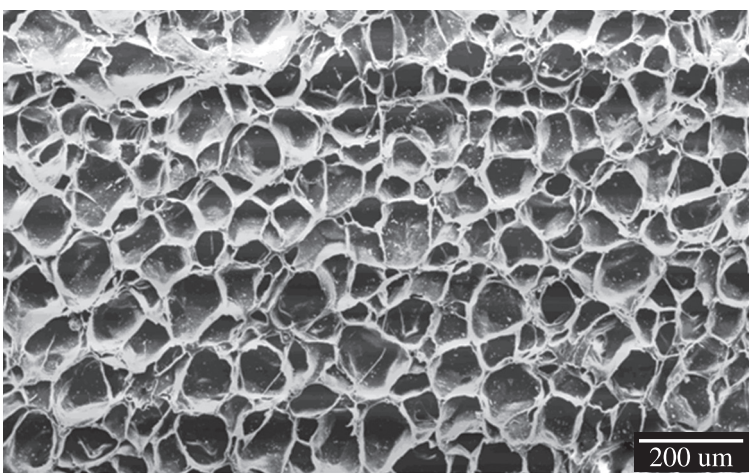

(b)

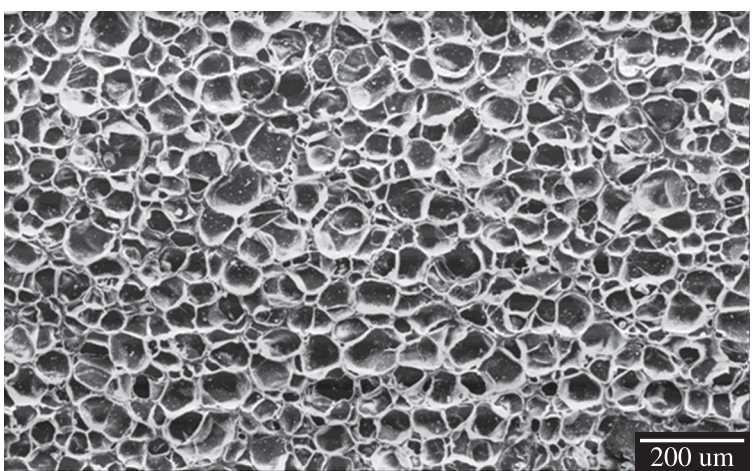

(c)

Figura 16. Micrografias de espumas de EVA /EPDM. a) Formulação com 0,2 pcr de agente de reticulação; b) formulação com 0,6 pcr de agente de reticulação; e c) formulação com 1,0 pcr de agente de reticulação.

\section{Caracterização morfológica}

A Figura 16 ilustra algumas micrografias obtidas com espumas contendo 70 pcr de EVA e 30 pcr de EPDM onde foram variadas as concentrações de agente de reticulação.

Por meio das imagens obtidas com a variação do agente de reticulação pode-se observar que as células são maiores para as que foram preparadas com uma menor concentração de agente de reticulação (Figura 16a-b). O aumento da reticulação restringe a expansão resultando em tamanho menor de células (Figura 16c), o que representa aumento da densidade da espuma e outras propriedades relacionadas a este parâmetro, como já discutidas anteriormente.

\section{Conclusão}

A partir do estudo realizado com diferentes concentrações de peróxido de dicumila como agente de reticulação em formulações 
para obtenção de espumas com EVA/EPDM observou-se que tanto o agente de reticulação quanto o EPDM influenciam na cinética de cura dos compostos, alterando as curvas reométricas e os parâmetros de vulcanização.

A quantidade de agente de reticulação nas formulações das espumas influencia em todas as propriedades físicas e mecânicas do produto final, provavelmente pela mudança no grau de reticulação que afeta a viscosidade da massa em expansão e, assim, sua habilidade na geração das células. Das propriedades estudadas, a dureza externa apresentou a maior dependência com o teor de agente reticulante presente. Por meio da análise morfológica, pode-se observar que com o aumento da concentração de agente de reticulação o tamanho das células é reduzido. Esse balanço de resultados permite selecionar combinações mais apropriadas para aplicações específicas, valorizando suas as propriedades de interesse como leveza, rigidez ou resistência mecânica.

\section{Agradecimentos}

Os autores agradecem ao Instituto de Química da UFBA e a Saargummi do Brasil.

\section{Referências Bibliográficas}

1. Almeida, M. G. - "Incorporação de polietileno pós- consumo em espumas de polietileno de baixa densidade", Dissertação de Mestrado, Universidade de Caxias do Sul (2006).

2. Rabello, M. S. - "Aditivação de polímeros", Artliber Editora, São Paulo (2000).

3. Klempner, D. \& Frisch, K. C. - "Handbook of polymeric foams", Hanser, Munich (1991).

4. Alemany, F. J. S. - "Estúdio de los procesos de reticulado, espumado y decomposición y descomposición térmica de formulaciones industriales de copolímeros de EVA y PE: métodos cinéticos", Tese de Doutorado, Universidade de Alicante (2002).

5. Youssef, H. A.; Senna, M. M. \& Eyssa, H. M. - J. Polym. Res., 14, p.351 (2007)

6. Mahapatro, A.; Mills, N. J. \& Sims, G. L. A. - Cell. Polym., 17, p.252 (1998).

7. Sipaut, C. S.; Sims, G. L. A. \& Ariff, Z. M. - Cell. Polym., 27, p.11 (2008).
8. Peters, R.; van Duin, M.; Tonoli, D.; Kwakkenbos, G.; Mengerink, Y.; van Benthem, K.; Schoenmakers, P. J. \& van der Wal, S. J. - J. Chromatography, 1201, p.151 (2008).

9. Rai, I. \& Khastgir, D. - Plast. Rubb. Compos. Proc. Appl., 22, p.305 (1994).

10. Blow, C. M. \& Hepburn, C. - "Rubber techonology and manufacture", Butterworths, London (1982).

11. Munteanu, D. in: "Plastics Additives Handbook", Zweifel H. (ed.), Munich, Hanser (2001).

12. Mukherjee, A. K.; Gupta, B. D. \& Sharma, P. K. - JMS - Rev. Macromol. Chem. Phys., C26, p.415 (1986).

13. Hofmann, W. - "Rubber Technology Handbook", Hanser, Munich (1989).

14. Liu, C. P. \& Lin, J. H. - J. Appl. Polym. Sci., 106, p.897 (2007).

15. Shyichuk, A. V. \& Tokaryk, G. - Polimery, 47, p.548 (2000).

16. De Paoli, M. A. - "Degradação e estabilização de polímeros", Artliber, São Paulo (2009).

17. Acharya, H.; Kuila, T.; Srisvastava, S. K. \& Bhowmick, A. K. - Polym. Comp., 29, p.443 (2008).

18. Misha, S.; Balakrishnan, S. \& Chandra, R. - J. Appl. Polym. Sci., 70, p.1929 (1998).

19. Liu, C. \& Lin, J. - J. Appl. Polym. Sci., 106, p.897 (2007).

20. Alpire, M. C.; Azevedo, J. B. \& Rabello, M. S. in: Anais do $9^{\circ}$ CBPOL, Campina Grande, PB (2007)

21. Vedoy, D. R. L. - "Compostos de EVA modificados com resinas hidrocarbônicas", Dissertação de Mestrado, UFRGS (2006).

22. Alpire, M. C. - "Influência do carbonato de cálcio nas propriedades físicas de espumas de EVA", Dissertação de Mestrado, UFCG (2007).

23. Oliveira, M. G. \& Soares, B. G. - Polimeros, 12, p.11 (2002).

24. Azevedo, J. B.; Alpire, M. C.; Rabello, M. S. \& Oliveira R. G. P. - Rev. Eletr. Mat. Proc., 4, p.38 (2009).

25. Birley, A.W.; Haworth, B. \& Batchelor, J. - "Physics of Plastics", Hanser, Munich (1992).

Enviado: 10/03/10

Reenviado: $14 / 05 / 10$

Aceito: 03/07/10

DOI: $10.1590 / \mathrm{S} 0104-14282011005000002$ 